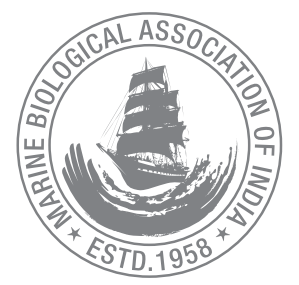

\title{
Growth and survival of the blacklip pearl oyster Pinctada margaritifera (Linnaeus) spat reared with various combinations of microalgae in different stocking densities
}

\author{
C. Linoy Libini ${ }^{\star}$, K. A. Albert Idu, C. C. Manjumol, V. Kripa ${ }^{1}$ and K. S. Mohamed ${ }^{1}$ \\ Blacklip Pearl Oyster Laboratory of CMFRI, Fisheries Training Centre, Marine Hill, Port Blair 744101, Andaman and \\ Nicobar Islands. \\ 'Central Marine Fisheries Research Institute, PO Box 1603, Kochi 682 018, Kerala, India. \\ *Correspondence e-mail: linoylibini@gmail.com
}

Received: 15 Oct 2013, Accepted: 18 Jun 2014, Published: 15 Jul 2014

Original Article

\begin{abstract}
The present study has revealed that, the temperature has a crucial role among the observed physiochemical parameters on the growth and survival of $P$. margaritifera spat. Instantaneous growth rates (IGRs) in DVM, APM and TWT were calculated and used to assess the variation in growth of spat reared with different feed mixtures (FM-1 - 8) of five diatoms and stocking densities (SD-10, 20 and 30). Among all treatments, FM-3, 4 and 5 gave better performance than that all other combinations of diatoms. Chaetoceros calcitrans, Nannochloropsis oculata and Chlorella marina was formed major shares (60\%) respectively in combination with $10 \%$ each of rest of algae. FM-7 which had all diatoms in equal (20\%) measure performed as the next best feed combination. Poor growth was observed in spat fed with FM-2 which was dominated by Isochrysis galbana (60\%) and FM-6 which comprised of an equal measure (30\%) of Pavlova salina, Isochrysis galbana, Chaetoceros calcitrans and Nannochloropsis oculata and Chlorella marina at 5\% each. When the stocking density increases (SD-20 and 30) growth rates (IGRs) in all three variables decreased irrespective of feed combinations. Mortality rates varied in different treatments and also with stocking densities. Maximum mortality was observed in control (FM -8) in all the stocking densities. However, in all the feeding combinations and stocking densities, $100 \%$ survival was observed upto the $9^{\text {th }}$ DOC and mean cumulative mortalities showed a gradual increase. Comparatively very less cumulative mortality and better growth performance were recorded in stocking density, SD-10.
\end{abstract}

Keywords: P. margaritifera, spat growth, survival, microalgae, stocking densities.

\section{Introduction}

The blacklip pearl oyster, Pinctada margaritifera (Linnaeus) is well known for its ability to produce black pearls which are considered the queen of pearls. In India, hatchery technique for spat production of $P$. margaritifera was first initiated by Alagarswami, et al. (1989) and formed a continuous practice only in recent times (Mohamed, et al., 2010). Nursery rearing of spat in the sea and in closed conditions are usually faced with several problems such as fouling, environmental stress, predation by fish and invertebrates which lead to high mortality (Alagarswami, et al., 1989; Coeroli, et al., 1984; Friedman and Southgate, 1999; Pouvreau and Prasil, 2001; Yukihira, et al., 2006). Hatchery production of spat is essential for the development and sustained development of the pearl industry in Andaman Islands, an area having low spat fall. To support this industry, it is necessary to have hatchery and improve the growth and survival of spat in the nursery system though right protocols. One of the main technical hurdles in this aspect is feed management. 
Microalgal culture remains a critical factor for commercial rearing of larvae of marine animals (Brown and Jeffrey, 1992; Helm, et al., 2004). In early life stages of bivalves, providing an adequate diet is essential to achieve good growth and survival of spat. Undoubtedly, a mixed diet will produce far better growth as has been previously demonstrated in several bivalves (Whyte et al., 1987; Fidalgo et al., 1994; Taylor et al., 1997a, b). Moreover, the growth of bivalve fed with a mixture of several algal species is often superior to that obtained when fed with only one algal species mainly because of the right balancing of nutrients (Fidalgo et al., 1994).

After settlement in the larval rearing tank, spat grow-out in the sea faces many problems such as predation, unmanageable environmental changes, and biofouling resulting in high mortality. To overcome these, spat have to be reared in controlled nursery rearing systems for attaining adequate strength and size to survive well in natural ecosystem before transferring them to open sea farming (Southgate and Beer, 2000). Very few studies have been done in this direction. In the present study combinations of selected microalgae were fed to the spat held in 3 different stocking densities to find out an ideal mixture of live feed so as to develop an efficient algal diet for nursery rearing of $P$. margaritifera spat. The assessment was done using five species of microalgae widely used in bivalve hatcheries throughout the world.

\section{Material and methods}

\section{Experiment design}

Hatchery produced 48 days old $P$. margaritifera spat measuring 2.5 to $4.5 \mathrm{~mm}$ DVM were stocked in 1 litre acrylic containers at a stocking density (SD) of 10, 20, $30 \mathrm{spat} / 500 \mathrm{ml}$. The experiments were carried out for 30 days. Water exchange $(100 \%)$ was done daily. Environmental variables like atmospheric temperature, water temperature, salinity, $\mathrm{pH}$ and dissolved oxygen were recorded daily using a PioNneer 65 portable multiparameter probe. Initially, spats were measured for anterior posterior measurement (APM) and dorso ventral measurement (DVM) individually using an ocular micrometer in Leica L2 microscope and wet weight (TWT) was taken for all spat in each container by a Shimadzu digital balance with an accuracy of $0.1 \mathrm{mg}$. Subsequently, the spat measurements were taken at intervals of three days till the closure of the experiment.

\section{Microalgae culture and feeding plan}

Microalgae Pavlova salina (Pav); Isochrysis galbana (Iso); Chaetoceros calcitrans (Cha); Nannochloropsis oculata (Nan); and Chlorella marina (Chl) were used in various combinations. Axenic cultures of these microalgae were maintained in an indoor laboratory by using Conway's medium with a photoperiod of $12: 12$ (light / dark), temperature of $24^{\circ} \mathrm{C}$ and salinity of $30 \mathrm{ppt}$. Cultures were harvested during exponential growth phase for feeding the spat. The feeding plan was adopted with these microalgal cultures and their ratios were given in Table 1. In all feed mixtures (FM - 1 to 8), the feeding ration and the percentage of each alga were constant and were formulated based on the size of Pavlova salina $(5 \mu \mathrm{m})$. FM -8 is constituted with low percentage of algae and treated as control. A Initial rations were started with 50,000 cell / ml I day and it was increased by 5000 cell/day every third day the feeding ratio was uniformly increased exponentially in all treatments throughout the period of experiment (Fig. 1). Each feed mixture (FM) was tested in triplicate in SD at the rate of 10, 20 and 30 numbers of spat and was carried out for 30 days of culture (DOC).

Table. 1 Feeding plans and percentage composition of each feed mixture adopted for the experiment

\begin{tabular}{llllll}
\hline \multicolumn{7}{c}{ Algal species and \% Composition } \\
\hline $\begin{array}{l}\text { Algal feeding } \\
\text { plans }\end{array}$ & $\begin{array}{l}\text { Pavlova salina } \\
\text { (Pav) }\end{array}$ & $\begin{array}{l}\text { Isochrysis galbana } \\
\text { (Iso) }\end{array}$ & $\begin{array}{l}\text { Chaetoceros } \\
\text { calcitrans (Cha) }\end{array}$ & $\begin{array}{l}\text { Nannochloropsis } \\
\text { oculata (Nan) }\end{array}$ & $\begin{array}{l}\text { Chlorella marina } \\
\text { (Chl) }\end{array}$ \\
\hline $\begin{array}{l}\text { Ration based on } \\
\text { Pavlova sp. }\end{array}$ & 1 Pav =1 Pav & 1 Iso = 2 Pav & 1 Cha = 3 Pav & 2 Nan = 1 Pav & 3 Chl = 1 Pav \\
\hline FM-1 & 60 & 10 & 10 & 10 & 10 \\
\hline FM-2 & 10 & 60 & 10 & 10 & 10 \\
\hline FM-3 & 10 & 10 & 60 & 10 & 10 \\
\hline FM-4 & 10 & 10 & 10 & 60 & 10 \\
\hline FM-5 & 10 & 10 & 10 & 10 & 60 \\
\hline FM-6 & 30 & 30 & 30 & 5 & 5 \\
\hline FM-7 & 20 & 20 & 20 & 20 & 20 \\
\hline FM-8 control) & 4 & 4 & 4 & 4 & 4 \\
\hline
\end{tabular}




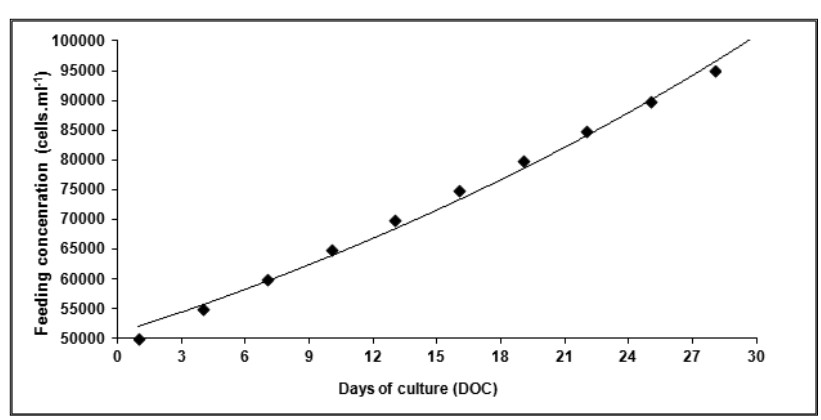

Fig 1. Feeding ratio in all the treatments during the period of experiment.

The mean APM, DVM and TWT were used for calculation of instantaneous growth rate (IGR) based on formula of Hopkins (1992).

$$
\mathrm{IGR}=\frac{L n_{t}-L n_{i}}{t}
$$

Where, $L n_{t}$ is the natural log of the length at time $t$ and $L n_{i}$ is the natural log of the initial length. IGRs values of DVM, APM and TWT between different feed mixtures were compared for significant differences using ANOVA. Attempts were also made to correlate IGRs and hydrological parameters in order to check for significant relationships with growth.

\section{Results and discussion}

\section{Hydrobiological parameters recorded during the study}

Water salinity, $\mathrm{pH}$ and dissolved oxygen content of sea water were similar in all treatment and hence their effect on growth and survival of spat were similar. Water temperature varied with room temperature (Fig. 2). During the initial experiment period (up to $15 \mathrm{DOC}$ ), water temperature was slightly higher ranging between 27 to $28 \mathrm{zC}$ gradually declined $\left(25^{\circ} \mathrm{C}\right)$ up to $21 \mathrm{DOC}$ and thereafter showed an increase and reached $27^{\circ} \mathrm{C}$ at the end of experiment.

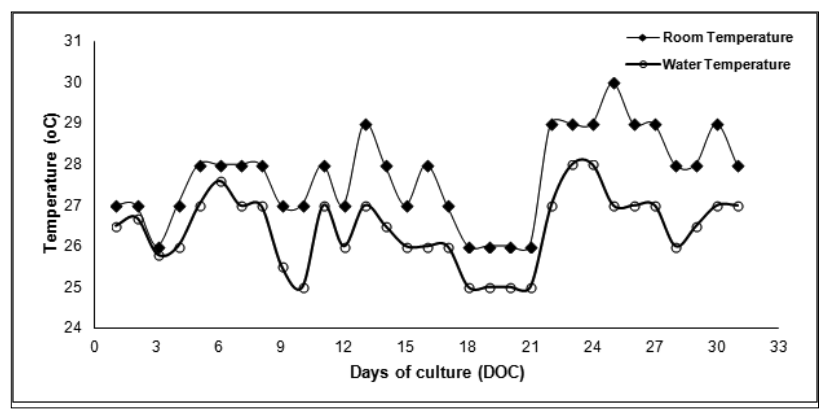

Fig 2. Temperature variations were recorded during the period of experiment.
Results of the present study showed that hydrological parameters particularly temperature may have influenced the spat growth. Spat growth of $P$. margaritifera will be maximum in an optimum or narrow range of temperature $\left(27-28^{\circ} \mathrm{C}\right)$ which is unique for each species. The higher than normal ambient air temperature resulted in higher water temperature which adversely affected the growth of the spat, as revealed by the correlation matrix (not shown) The slow increment in spat growth in early days of culture may be due to this influence of water temperature over growth. Growth increments of bivalves are known to be strongly influenced by exogenous factors such as food supply and water temperature (Thompson, 1984) and stocking density (Chellam, 1978).

Lucas (2008) observed that increase in water temperature positively influenced the ingestion rate in pearl oysters by increasing respiration and metabolic rate. Saucedo et al. (2004) reported that in $P$. mazatlanica the metabolic activity was affected at high and low level of temperature. In Indian pearl oyster $P$. fucata Alagarswami et al. (1983) observed that a good larval growth between $24-29^{\circ} \mathrm{C}$. Mills (2000) reported that temperature ranging between $20-29^{\circ} \mathrm{C}$ gives good spat growth in $P$. maxima. This was supported by the findings of Mondal (2006) that the clearance rate of $P$. fucata reduced considerably at water temperature above $28^{\circ} \mathrm{C}$. In P. margaritifera, it reportedly declined over $28^{\circ} \mathrm{C}$ to $32^{\circ} \mathrm{C}$ but in $P$. maxima the clearance rate remained steady under the same conditions (Yukihira et al., 1998). During the present experiment wide fluctuation in temperature $\left(27^{\circ} \mathrm{C}\right.$ to $\left.25^{\circ} \mathrm{C}\right)$ was observed from 9 to $21 \mathrm{DOC}$, the period which also recorded the highest mortality $(10-40 \%)$ in all feeding types irrespective of the stocking density. However, significant correlations could not be detected between IGRs and water temperature. A positive relationship between growth rate and water temperature in pearl oysters has been reported by many authors (Yukihira et al., 2000; Pouvreau and Prasil, 2001) in correlation with metabolic rate and feeding activity.

\section{Spat growth fed with various feed combinations}

Instantaneous growth rates (IGRs) in DVM, APM and TWT were calculated and used to assess the variations in growth of spat reared with different feed mixtures (FM-1-8) and stocking densities (SD-10, 20 and 30) (Fig. 3). Among all treatments, FM-3, 4 and 5 gave better performance than that all other combinations of diatoms. In FM-3 Chaetoceros calcitrans was the major diatom while in FM-4 Nannochloropsis oculata formed major diatom and in FM-5 Chlorella marina the major diatom in combination with $10 \%$ each of rest of algae. Poor IGR values of DVM, APM and TWT were observed in spat fed with FM-2 which was dominated by Isochrysis galbana 


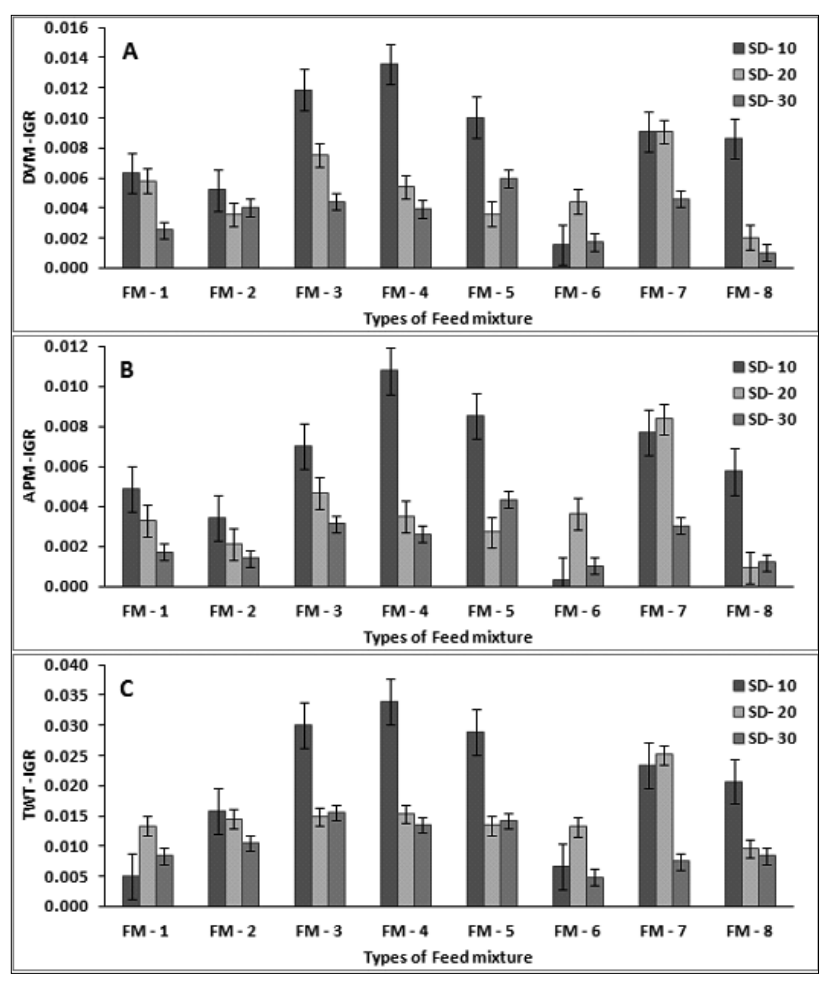

Fig 3. Instantaneous growth rates (IGRs) in DVM, APM and TWT of $P$. margaritifera spat reared with various feed mixtures (FM $1-8)$ in different stocking densities (SD - 10, 20,30)

$(60 \%)$ and FM-6 which comprised of an equal measure (30\%) of Pavlova salina, Isochrysis galbana, Chaetoceros calcitrans and Nannochloropsis oculata and Chlorella marina at 5\% each. FM-7 which had all diatoms in equal (20\%) measure performed as the next best feed combination. ANOVA did not show any significant $(P>0.05)$ differences in the IGRs between different feed combinations.

According to Yukihira et al. (1998), scope for growth (SFG) is very dependent on environmental conditions, especially food availability. In farming system many species of microalgae along with particulate organic matter are available to pearl oysters so the probability of nutritional deficiency is negligible.
However, in hatchery conditions, oysters are fed only a few species of algae and their nutritional composition is a vital factor on growth and survival. In the present study five species of microalgae, namely Pavlova salina, Isochrysis galbana, Chaetoceros calcitrans, Nannochloropsis oculata and Chlorella marina were used. These are the common algal species used in hatchery and nursery rearing of bivalve molluscs worldwide (Coutteau and Sorgeloos, 1992; Helm et al., 2004). In the present study we used here in different feed combinations dominated by a single species or as an equal mixture of all. Among the different feed mixtures, better growth was observed when fed with FM-3 and 4 which were dominated with Chaetoceros calcitrans and Nannochloropsis oculata respectively. Taylor et al., (1997c) observed good growth and survival of $P$. maxima spat fed with 1:1 ratio of Chaetoceros calcitrans and Isochrysis galbana. Nannochloropsis oculata has also been used as feed for $P$. maxima larvae (Rose and Baker, 1994). FM-2 a mix dominated with Isochrysis galbana showed poor growth performance. Similarly FM-6 resulted in slow growth even though the feed had Pavlova salina, Isochrysis galbana and Chaetoceros calcitrans in equal proportions (30\% each).

\section{Spat growth fed with respect to stocking densities}

IGR values of DVM, APM and TWT showed comparatively high rates in SD-10 with all feed combinations except FM-6 (Fig. 3). However, FM-4 showed the maximum IGR values and minimum was in spat fed with FM-6. When the stocking density increases (SD-20 and 30) growth rates (IGRs) in all three variables decreased irrespective of feed combinations. However, IGR values were similar in low and medium stocking (SD-10 and 20) for spat fed with FM-7 which comprises of equal shares (20\%) of the all five species of algae used in the experiment. ANOVA carried showed that variations in IGRs with different spat stocking densities was significant $(\mathrm{P}<0.05)$ (Table 2).

Table. 2 Variations in growth parameters (IGR-DVM, IGR-APM and IGR-TWT) on different feed mixtures (FM 1-8) and Stocking densities (SD - 10, 20, 30).

\begin{tabular}{llllllll}
\hline $\begin{array}{l}\text { Growth } \\
\text { Parameters }\end{array}$ & $\begin{array}{l}\text { Source of } \\
\text { Variation }\end{array}$ & SS & df & MS & F & P-value & F crit \\
\hline \multirow{2}{*}{ IGR- DVM } & FM $(1-8)$ & $8.63 \mathrm{E}-05$ & 7 & $1.23 \mathrm{E}-05$ & 2.382 & 0.079 & 2.764 \\
\cline { 2 - 8 } & SD10,20,30 & $9.27 \mathrm{E}-05$ & 2 & $4.64 \mathrm{E}-05$ & 8.962 & 0.003 & 3.739 \\
\hline \multirow{2}{*}{ IGR- APM } & FM $(1-8)$ & $6.38 \mathrm{E}-05$ & 7 & $9.11 \mathrm{E}-06$ & 2.416 & 0.076 & 2.764 \\
\cline { 2 - 8 } & SD10,20,30 & $5.70 \mathrm{E}-05$ & 2 & $2.85 \mathrm{E}-05$ & 7.555 & 0.006 & 3.739 \\
\hline \multirow{2}{*}{ IGR-TWT } & FM $(1-8)$ & $5.34 \mathrm{E}-04$ & 7 & $7.62 \mathrm{E}-05$ & 2.117 & 0.110 & 2.764 \\
\cline { 2 - 8 } & SD10,20,30 & $4.18 \mathrm{E}-04$ & 2 & $2.09 \mathrm{E}-04$ & 5.800 & 0.015 & 3.739 \\
\hline
\end{tabular}


The growth increment in $P$. margaritifera was influenced by the spat stocking density and temperature. DVM and APM measurements of spat stocked in various stocking densities did not show similar growth trend. Spat stocked in SD-10 and 20 showed slow growth initially and improved after the rise of temperature from 21 DOC. In SD-30, none of the feed combinations have given a good growth increment. Instantaneous growth rates (IGRs) of DVM, APM and TWT showed comparatively high rates in SD-10 with all feed combinations except FM- 6 and as the stocking density increased the IGRs decreased. The unsteady IGR trends and related irregularities are seemed to be influenced by the differences in temperature. Similarly, del Rio-Portilla et al. (1992) reported that, the growth of Pteria sternawas influenced by a synergistic effect of temperature and food concentration. Yukihira et al. (1998) reported that scope for growth (SFG) of $P$. margaritifera spat peaked at cell concentrations from

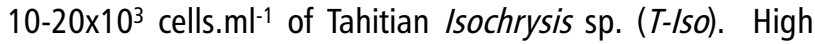
feed concentrations have been found to markedly increase the clearance rate and adversely affect the rate of absorption and reduction of SFG in bivalves (Mike and Ward, 2003). In the present study, initial feed concentration has started by $50 \times 10^{3}$ cells. $\mathrm{ml}^{-1}$ and an increase of $5 \times 10^{3}$ cells. $\mathrm{ml}^{-1}$ in every third day. However, the reduction in growth performance in SD-30 may be due to comparatively low levels of algal cells available to the individual spat. Such correlation between pearl oyster growth and food availability has also been shown in field studies (Numaguchi, 1994: Pouvreau et al., 2000) and in laboratory studies with juveniles and larvae (del Rio-Portilla et al., 1992; Doroudi et al., 1999; Doroudi and Southgate, 2002).

\section{Rate of mortality in feed combinations in various stocking densities}

Mortality rates varied in different treatments and also with stocking densities. Maximum mortality was observed in control (FM-8) in all the stocking densities. In all the feeding combinations and stocking densities, $100 \%$ survival was observed upto the $9^{\text {th }}$ DOC and mean cumulative mortalities showed a gradual increase and was below $50 \%$ at 30 DOC in the all feed mixtures except in control (Fig. 4). Comparatively very less cumulative mortality was recorded in stocking density, SD-10.

In SD-10, spat mortality was more in spat fed with FM-8, 1 and 6 and less mortality was observed in spat fed with feeds, FM-3, 2, and 7 (Fig. 4a). In the case of spat in SD-20, maximum mortality was observed in those fed with feed mixtures FM-8, 7 and 6 and the minimum was observed with FM-2, 1 and 5 (Fig. 4b). However, in SD-30, the rate of mortality was high in spat fed with feed mixtures, FM-8, 2 and 3 and low with FM-1,
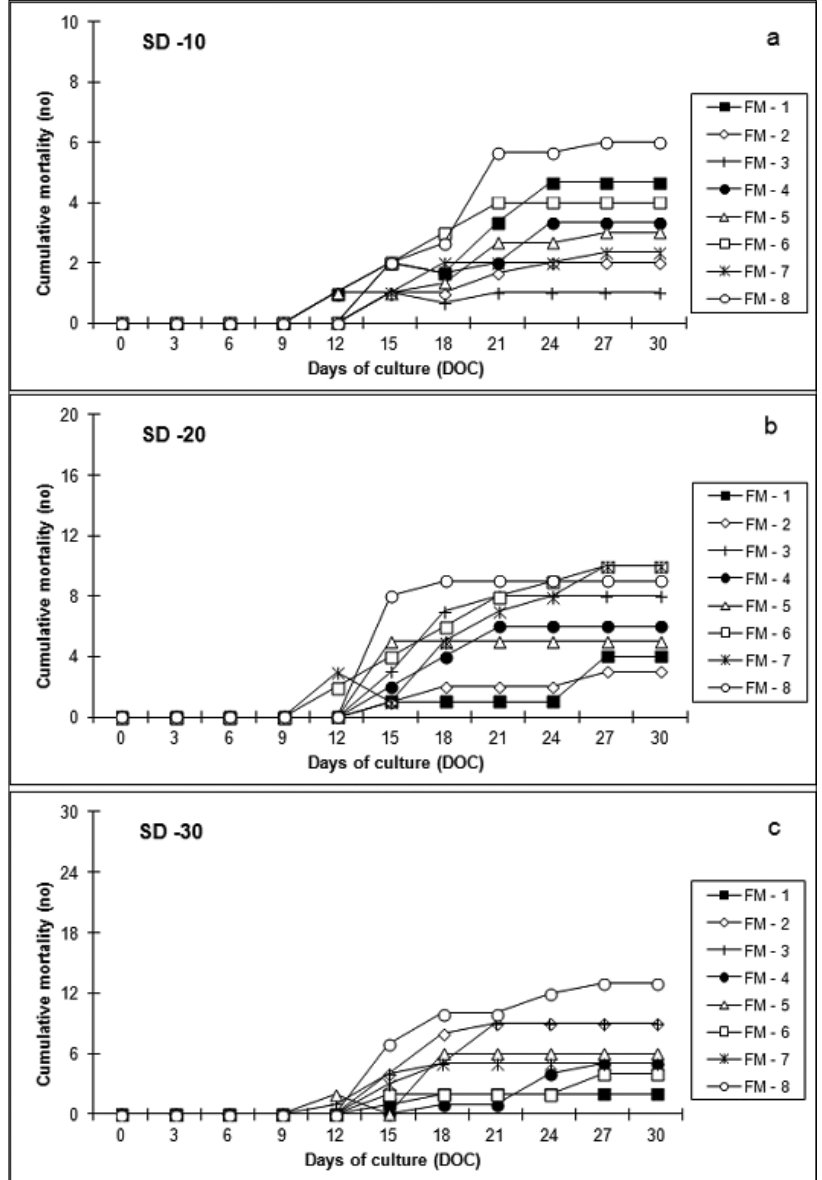

Fig 4. Instantaneous growth rates (IGRs) in DVM, APM and TWT of P. margaritifera spat reared with various feed mixtures (FM 1 - 8) in different stocking densities (SD - 10, 20,30)

6 and 4 (Fig. 4c). Food particles available to pearl oysters must be of an appropriate size and have favourable morphology to allow ingestion and digestion. Growth rates of pearl oysters are strongly influenced by the nutritional composition of ingested food particles (Taylor et al., 1997b; Southgate et al., 1998; Martinez-Fernandez et al., 2006; Martinez-Fernandez and Southgate, 2007).

The present study has emphasised that the growth and survival of $P$. margaritifera spat in nursery are influenced by several factors. Among the feed mixtures tried out in the study, a combination of algae used in FM-3 and FM-4 were found ideal for spat rearing in hatchery conditions. Comparatively high cumulative mortality was recorded in higher stocking density. However, the feed mixtures did not show any influence on mortality rate with respect to stocking densities except control. It also revealed that a stocking density of 10 spat per $500 \mathrm{ml}$ as an ideal stocking density with an optimum temperature ranging between $27-28^{\circ} \mathrm{C}$ for maximum growth performance. However, a complete nutritional composition 
status and ingestion, digestion rates of forage algal species have to be done before reaching firm conclusions.

\section{Acknowledgements}

The authors are thankful to the Director, CMFRI, Kochi for facilities. They are grateful to the Ministry of Earth Sciences, New Delhi for funding a project on blacklip pearl oyster farming in which this work was carried out.

\section{References}

Alagarswami, K., S. Dharmaraj, A. Chellam and T. S. Velayudhan. 1989. Larval rearing and juvenile rearing of the blacklip pearl oyster Pinctada margaritifera. Aquaculture, 76: 43- 56.

Alagarswami, K., S. Dharmaraj, T. S. Velayudhan, A. Chellam, A. C. C. Victor and A. D. Gandhi. 1983. Larval rearing and production of spat of pearl oyster Pinctada fucata. Aquaculture, 34: 287- 302.

Brown, M. R. and S. W. Jeffrey. 1992. The nutritional properties of microalgae used in mariculture: an overview. In: Allen, G., and L. Dall (Eds.). Proceedings of Aquaculture Nutrition Workshop, April 15-17, 1991, Salamander Bay. NSW Fisheries, Brackish Water Fish Culture Research Station, Salamander Bay, Australia, pp. 174- 179.

Chellam, A. 1978. Growth of pearl oyster Pinctada fucata in the pearl farm at Veppalodai. Indian J. Fish., 25: 77- 83.

Coeroli, M., D. De Gaillande and J. P. Landret. 1984. Recent innovations in cultivation of molluscs in French Polynesia. Aquaculture, 39: 45- 67.

Coutteau, P. and P. Sorgeloos. 1992. The requirement for live algae and their replacement by artificial diet in the hatchery and nursery rearing of bivalve molluscs: an international survey. J. Shellfish Res., 11(2): 467- 476.

del Rio-Portilla, M. A., A. D. Re-Araujo and D. Voltolina. 1992. Growth of the pearl oyster Pteria sterna under different thermic and feeding conditions. Mar. Ecol. Prog. Ser., 89: 221- 227.

Doroudi, M. and P. C. Southgate. 2002. The effect of chemical cues on settlement behaviour of blacklip pearl oyster (Pinctada margaritifera) larvae. Aquaculture, 209: 117- 124.

Doroudi, M., P. C. Southgate and R. Mayer. 1999. The combined effects of temperature and salinity on embryos and larvae of the blacklip pearl oyster, Pinctada margaritifera. Aquacult. Res., 30: 1 - 7.

Fidalgo, J. P., A. Cid, I. Lopez-Munoz, J. Abalde and C. Herrero. 1994. Growth and biochemical profile of juvenile mussels (Mytilus galloprovincialis) fed on different algal diets. J. Shellfish. Res., 1: 67- 75.

Friedman, K. J. and P. C. Southgate.1999. Grow out of blacklip pearl oysters, Pinctada margaritifera collected as wild spat in the Solomon Islands. J. Shellfish. Res., 18: 159-167.

Helm, M. M., N. Bourne and A. Lovatelli. 2004. Hatchery culture of bivalves. A practical manual. FAO Fisheries Technical Paper, 471. Rome, FAO. 177pp.

Hopkins, K. D. 1992. Reporting fish growth: A review of the basics. J. World Aquac. Soc., 23: 173- 179

Lucas, J. S. 2008. Feeding and metabolism. In: Southgate P. C. and J. S. Lucas (Eds.) The pearl oyster: Biology and culture. Elsevier, London. p. 103- 130.

Martínez-Fernández, E., H. Acosta-Salmón and P. C. Southgate. 2006. The nutritional value of seven species of tropical microalgae for blacklip pearl oyster (Pinctada margaritifera) larvae. Aquaculture, 257: 491- 503.
Martínez-Fernández, E. and P. C. Southgate. 2007. Use of tropical microalgae as food for larvae of the blacklip pearl oyster Pinctada margaritifera. Aquaculture, 263: 220- 226.

Milke, L. M. and J. E. Ward. 2003. Influence of diet on pre-ingestive particle processing in bivalves. II: Residence time in the pallial cavity and handling time on the labial palps. J. Exp. Mar. Biol. Ecol., 293: 151- 172

Mills, D. 2000. Combined effects of temperature and algal concentration on survival, growth and feeding physiology of Pinctada maxima spat. J. Shellfish Res., 19: 159- 166.

Mohamed, K. S., V. Kripa, C. L. Libini, K. Shanmugam, K. P. Rao and T.S. Velayudhan. 2010. Hatchery production of blacklip pearl oyster spat in the Andaman and Nicobar islands: A success story. Fishing Chimes, 30: 40- 41.

Mondal, S. K. 2006. Effect of temperature and body size on food utilization in the marine pearl oyster Pinctada fucata (Bivalvia: Pteridae). Indian J. Mar. Sci., 35: 43- 49.

Numaguchi, K. 1994. Growth and physiological condition of the Japanese pearl oyster, Pinctada fucata martensii in Ohmura Bay, Japan. J. Shellfish. Res., 13: 93- 99.

Pouvreau, S. and V. Prasil. 2001. Growth of the blacklip pearl oyster, Pinctada margaritifera at nine culture sites in French Polynesia: Synthesis of several sampling designs conducted between 1994 and 1999. Aquat. Living Res., 145: $155-163$.

Pouvreau, S., A. Bodoy and D. Buestel. 2000. In situ suspension feeding behaviour of the pearl oyster, Pinctada margaritifera: Combined effects of body size and weather-related seston composition. Aquaculture, 181: 91- 113.

Rose, R. A. and S. B. Baker. 1994. Larval and spat culture of the western Australian silver-or gold lip pearl oyster, Pinctada maxima Jameson (Mollusca): Pteriidae. Aquaculture, 126: 35- 50.

Saucedo, P. E., L. Ocampo, M. Monteforte and H. Bervera. 2004. Effect of temperature on oxygen consumption and ammonia excretion in the Calafia mother of pearl oyster, Pinctada mazatlantica. Aquaculture, 229: 377- 387.

Southgate, P. C. and A. C. Beer. 2000. Growth of blacklip pearl oyster (Pinctada margaritifera) juveniles using different nursery culture techniques. Aquaculture, 187: 97- 104.

Southgate, P. C., A. C. Beer, P. F. Duncan and R. Tamburri. 1998. Assessment of the nutritional value of three species of tropical microalgae, dried Tetraselmis and a yeast-based diet for larvae of the blacklip pearl oyster, Pinctada margaritifera. Aquaculture, 162: 247- 257.

Taylor, J. J., P. C. Southgate and R. A. Rose. 1997a. Fouling animals and their effect on the growth of silver-lip pearl oysters, Pinctada maxima in suspended culture. Aquaculture, 153: 31- 40.

Taylor, J. J., R. A. Rose, P. C. Southgate and C. E. Taylor. 1997b. Effects of stocking density on growth and survival of early juvenile silver-lip pearl oysters Pinctada maxima, held in suspended nursery culture. Aquaculture, 153: 41- 49.

Taylor, J. J., P. C. Southgate, M. S. Wing and R. A. Rose. 1997c. The nutritional value of five species of microalgae for spat of the silver-lip pearl oyster, Pinctada maxima (Mollusca:Pteriidae). Asian Fisheries Sci. 10: 1- 8.

Thompson, R. J. 1984. Production, reproductive effort, reproductive value and reproductive cost in a population of blue mussel Mytilus eduli s from a subartic environment. Mar. Ecol. Prog. Ser., 16: 249- 257.

Whyte, J. N. C., N. Bourne and C. A. Hodgson. 1987. Assessment of biochemical composition and energy reserves in larvae of the scallop Patinopecten yessoensis. J. Exp. Mar. Biol. Ecol., 113: 113- 124.

Yukihira, H., D. W. Klumpp and J. S. Lucas. 1998. Effects of body size on suspension feeding and energy budgets of the pearl oysters Pinctada margaritifera and $P$. maxima. Mar. Ecol. Prog. Ser., 170: 119- 130.

Yukihira, H., J. S. Lucas and D. W. Klumpp. 2000. Comparative effects of temperature on suspension feeding and energy budgets of the pearl oysters Pinctada margaritifera and P. maxima. Mar. Ecol. Prog. Ser., 195: 179- 188.

Yukihira, H., J. S. Lucas and D. W. Klumpp. 2006. The pearl oysters, Pinctada maxima and $P$. margaritifera, respond in different ways to culture in dissimilar environments. Aquaculture, 252: 208- 224. 